\title{
EN LO PROFUNDO DE LA FRÁGIL MEMORIA: LOS “OTROS” SECRETARIOS DEL SANTO OFICIO
}

\author{
DEEP INTO FRAGILE MEMORY: \\ THE OTHER SECRETARIES OF THE HOLY OFFICE
}

\author{
Bárbara SANTIAGO MEDINA \\ Universidad Complutense de Madrid
}

Resumen: Los secretarios del secreto constituyeron un elemento fundamental de la estructura de los tribunales de distrito del Santo Oficio durante todo el tiempo que la institución se mantuvo en funcionamiento. Tenían encomendada la redacción de documentos y el cuidado del archivo, pero también otras muchas funciones, de manera que los secretarios no eran las meras representaciones burocráticas a las que la historiografía ha querido relegarles. De hecho la excesiva carga de trabajo que, en ocasiones, habían de soportar, llevó a que, lo que en un principio era un oficio unitario bien definido, empezara a desdoblarse en toda una compleja tipología de figuras que compartían sus desvelos, pero no sus privilegios. El presente artículo tiene como objetivo profundizar en aquellos individuos que, ajenos al rango de oficiales, participaron del trabajo de la secretaría del secreto en los tribunales inquisitoriales.

Palabras clave: Inquisición española, Historia Moderna, Burocracia, Documentación.

\footnotetext{
Abstract: The secretaries of the secret were an essential element of the Holy Office's district courts. They were in charge of recording and writing all of the official documents of these tribunals, but also of keeping the archive in order. And not only of these, so they were not the simple bureaucrats that the traditional historians wrote about. In fact, their long working hours turned a unique and much defined office into a complex taxonomy of professionals who shared the secretaries of the secret's concerns but not their privileges. This paper aims to go in depth into these professionals' current life. They were not officials, but they take care of some important duties even if they were not getting paid for it.
} 
BÁRbara SANTIAGO MEDINA
EN LO PROFUNDO DE LA FRÁGIL MEMORIA: LOS “OTROS” SECRETARIOS DEL SANTO OFICIO

Keywords: Spanish Inquisition, Early Modern History, Bureaucracy, Documents.

\section{INTRODUCCIÓN}

A pesar del olvido historiográfico en que, desafortunadamente, han caído los secretarios del secreto, es posible afirmar que constituían uno de los principales engranajes de la maquinaria del Santo Oficio. Sin ellos, la Inquisición española nunca hubiese podido desempeñar sus funciones con normalidad, ya que sus quehaceres eran del todo imprescindibles en casi cualquier actividad que llevaba a cabo la institución. Eran funcionarios titulados de pleno derecho y recibían su nombramiento del mismísimo Inquisidor General, quien les promovía al oficio tras haber tenido en cuenta toda una serie de factores de muy distinta índole (personales, económicos, políticos, protocolarios.... $)^{1}$.

La presencia de los secretarios o notarios, pues reciben ambas denominaciones en la documentación, está constatada desde los mismos orígenes de la institución, acompañando a los inquisidores en su labor y dejando testimonio escrito de sus actuaciones procesales ${ }^{2}$. Sin embargo, la falta de documentación administrati-

\footnotetext{
${ }^{1}$ Hasta la fecha, ninguna monografía se ha dedicado por completo al estudio de la figura de los secretarios del secreto, mientras que los capítulos de libros o artículos son todavía muy escasos. Entre ellos: $\mathrm{M}^{\mathrm{a}} \mathrm{J}$. TORQUEMADA SÁNCHEZ, "Los secretarios o notarios del secreto en Sevilla desde comienzos del siglo XVIII", en E. GACTO FERNÁNDEZ (coord.), El centinela de la fe: Estudios jurídicos sobre la Inquisición de Sevilla en el siglo XVIII, Sevilla, 1997, pp. 15-94; B. SANTIAGO MEDINA, "Manuel Viñals de la Torre y el Archivo de la Inquisición de Barcelona (1705-1723), Revista General de Información y Documentación, XV/2 (2005), pp. 157-183; B. SANTIAGO MEDINA, "Los señores del secreto: Historia y documentación de los secretarios del Santo Oficio madrileño", en N. ÁVILA SEOANE (coord.), J. C. GALENDE DÍAZ y S. CABEZAS FONTANILLA (dirs.), Paseo documental por el Madrid de antaño, Madrid, 2015, pp. 349374; B. SANTIAGO MEDINA, "Pablo García, notario del secreto: Retazos de una vida al servicio del Santo Oficio", en F. LORENZANA DE LA PUENTE y F. J. MATEOS ASCACÍBAR (coords.), Inquisición, Llerena, 2014, pp. 109-122.

${ }^{2}$ En el presente artículo, por influencia de la propia documentación y para evitar reiteraciones en el discurso, utilizaré de manera indistinta los términos "secretario" y "notario" para referirme a estos servidores del Santo Oficio. A pesar de que ellos, con el tiempo, tendieron a denominarse a sí mismos como "secretarios", abandonando el calificativo de "notarios" con el que se les denominaba en los inicios de la institución, sin duda en busca de reconocimiento social y laboral, pero también para distanciarse de los notarios de distrito, quienes carecían del título de oficiales y a los que se consideraba simples colaboradores.

Por las noticias localizadas en los registros de una visita de inspección al Tribunal de Sevilla, se sabe que la Suprema, al menos para ese distrito, estipuló en una carta acordada de 29 de noviembre de 1638 que los "notarios del secreto", en los testimonios que dieren y otros autos en que entren hablando, no se llamen ni refrenden con título de secretarios, sino de notarios del secreto. Pero los "notarios" sevillanos no lo habían respetado, antes bien, en los testimonios que ha dado
} 
va procedente de los más antiguos tribunales de distrito en sus épocas de formación y establecimiento, conduce al práctico desconocimiento acerca de quiénes fueron estos primeros secretarios. Por su intervención en los textos es posible conocer su identidad, pero no así su origen, méritos o procedimiento por el cual fueron elegidos. Sin embargo, puede suponerse que su figura poco tendría que ver con la de sus sucesores en el oficio tiempo después.

Pero los secretarios del secreto no eran las únicas personas que trabajaban en esta oficina y archivo inquisitorial, el "secreto", y, afirmar lo contrario, es un tremendo error que muestra el desconocimiento y el olvido historiográficos, al que antes me refería y en que ha incurrido el ámbito de estudio de los tribunales de distrito $^{3}$. Antes bien, por el secreto discurren toda una suerte de oficiales numera-

en diferentes negoçios y otros autos, diciendo y llamándose, a ssí y a sus compañeros, de "secretarios” (Archivo Histórico Nacional, Inquisición, Legajo 1.856, expediente 5, fol. 76v).

La Profesora María Jesús Torquemada Sánchez, en su trabajo sobre los secretarios del secreto sevillanos del siglo XVIII, menciona cómo resulta difícil encontrar el apelativo de "notarios” para aludir a estos oficiales. Asimismo, transcribe parte de un "Abecedario" fechado en 1738 que daría noticia del motivo por el cual apenas se hacía uso del término "notario”. Debido a su relevancia, he estimado conveniente hacerme eco de ese mismo texto para presentarlo en este artículo:

“Notarios”. Este nombre en la Inquisición es muy general y se distinguen conforme el ejercicio del oficio que cada uno tiene. A los que se ocupan en el secreto llaman "notarios del secreto"; a el que se ocupa en los secuestros, "notario de secuestros"; a el que se ejercita en el juzgado de bienes, "notario del juzgado", y algunas vezes "secretario del juzgado"; y a el que se ocupa en hacer los reconocimientos de los zensos del fisco, llaman "notario de acotaciones"; y a los que se ocupan con los comisarios en sus lugares, en los negocios de limpieza $y$ otros que se encargan a los dichos comisarios, los llaman "notarios del Santo Oficio". Y aunque todos son llamados con este nombre y sin distinción alguna, y así llaman a los del secreto las Instrucciones, Cartas Acordadas y otras Órdenes, que cada día vienen del Señor Inquisidor General y Consejo de Inquisición, observando lo primitivo, en cuyo tiempo aun a los secretarios inmediatos de los reyes los llamaban "notarios", hasta que con el tiempo, con el ejercicio de los oficios y gravedad de los negocios llamó a los más immediatos y que tocan negocios más superiores, "secretarios” y a los demás "notarios”. Por lo cual también ha introducido llamar "secretarios" a los del secreto de la Inquisición. Y es mucha razón, así por la gravedad y seriedad de las materias en que se ocupan y ante ellos pasan, como por la calidad de las personas que para estos oficios eligen siempre los Señores Inquisidores Generales, por lo cual, lo que a ellos toca, no se pone en la palabra "notarios", sino en la palabra “secretarios” (AHN, Inquisición, Libro 1.278, fol. 133v. Citado en Ma J. TORQUEMADA SÁNCHEZ, "Los secretarios o notarios del secreto en Sevilla desde comienzos del siglo XVIII”, en E. GACTO FERNÁNDEZ (coord.), El centinela de la fe: Estudios jurídicos sobre la Inquisición de Sevilla en el siglo XVIII, Sevilla, 1997, pp. 16-17).

${ }^{3}$ La existencia del "secreto", el archivo de los tribunales inquisitoriales de distrito, se constata ya en las “instrucciones” otorgadas por fray Tomás de Torquemada:

Que en cada Inquisición aya una arca o cámara de los libros, registros y escrituras del secreto, con tres cerraduras y tres llaves, y que de las dichas llaves, las dos tengan los dos notarios del Secreto y la otra el fiscal, porque ninguno pueda sacar escritura alguna sin que todos estén presentes [...]. Y que en la dicha cámara no entren sino solo los inquisidores y notarios del secreto y el fiscal (A. MANRIQUE: Copilación de las Instruciones del Oficio de 
BÁRBARA SANTIAGO MEDINA
EN LO PROFUNDO DE LA FRÁGIL MEMORIA: LOS “OTROS” SECRETARIOS DEL SANTO OFICIO

rios, jubilados, supernumerarios, así como ayudantes, con distintos grados de implicación, responsabilidades y, por supuesto, remuneración.

\section{LOS “OTROS” SECRETARIOS DEL SANTO OFICIO}

\subsection{Los secretarios supernumerarios}

Aunque el propio fray Tomás de Torquemada, en los albores del Santo Oficio, solo reconocía la existencia de notarios del secreto, entendiéndose por tales los que se denominarían "titulados”, con el paso del tiempo y el mayor volumen de trabajo existente en los tribunales de distrito, esta oficialía pasó a contar con unos colaboradores que gozaban de una vinculación más estrecha con la institución que los meros “ayudantes”, de los que se hablará más adelante, pues, a diferencia de estos, también recibían un título inquisitorial. Se trataba, por tanto, de oficiales nombrados, pero que excedían el número de los establecidos en los tribunales, siendo sus derechos también diferentes a los de los secretarios "numerarios", aunque sus funciones se asemejaran, al menos en parte. Es curioso, pero, por las solicitudes recibidas en los distritos y la Suprema para acceder a este oficio, puede deducirse que se consideraba un cargo completamente honorífico y no en vano a veces aparecen mencionados en la documentación como secretarios “honorarios". Por este motivo no percibían ningún tipo de remuneración por parte del Santo Oficio, algo que, por otra parte, sí podían hacer los ayudantes. Este hecho contrasta con la realidad de que, al recibir su nombramiento, se especificaba claramente cómo debían desarrollar su labor en el secreto. Es decir, trabajarían, pero sin salario, ayuda de costa u otro beneficio más que la distinción de formar parte de la insigne institución inquisitorial ${ }^{4}$.

la Santa Inquisición hechas por el Muy Reverendo Señor Fray Tomás de Torquemada, Prior del Monasterio de Santa Cruz de Segovia, primero Inquisidor general de los Reynos y Señoríos de España, Madrid: Imprenta Real, 1630, fol. 13r).

El texto anterior corresponde a una “instrucción” dirigida por Torquemada a los inquisidores de Barcelona, fechada en Granada, el día 4 de septiembre de 1499, pero no hacía otra cosa que reiterar lo que ya había ordenado, relativo al secreto, en otra instrucción anterior, promulgada en Ávila, en 1498 (Ibíd, fol. 16r).

${ }^{4}$ En 1741, los inquisidores de Valencia solicitaron a la Suprema un nombramiento de secretario honorario en favor de Vicente Salvador, hijo de uno de los secretarios del secreto del tribunal, Joseph Salvador, ya fallecido. En principio, no percibiría salario ni derechos, pero sí una pensión de 30 libras, no por su trabajo, sino como merced para ayuda de su familia, por haber sido solicitado así por su madre cuando su padre murió. La cantidad de 30 libras todavía estaba por decidir, ya que, sorprendentemente, sería asumida, no de manera directa por el tribunal, sino por otro de sus secretarios, Joachím Palavicino. El dinero sería descontado de su salario, de forma que éste tenía que estar de acuerdo, como de hecho estuvo, con la cantidad que se decidiese. 


\section{BÁRBARA SANTIAGo MEdina \\ EN LO PROFUNDO DE LA FRÁGIL MEMORIA: LOS “OTROS” SECRETARIOS DEL SANTO OFICIO}

Supeditados siempre a los secretarios numerarios, estos hombres apenas quedan reflejados en la documentación, y su labor, en algunos momentos, nada tenía que envidiar a la de aquellos. Solo en ciertas ocasiones los supernumerarios se significaban, pero, gracias a los textos generados entonces, es posible saber más acerca de ellos y su presencia en los tribunales. Ejemplo de ello es lo sucedido en Zaragoza en 1628, cuando los inquisidores de aquel distrito enviaron a la Suprema una petición de Gil Español del Niño, secretario honorario en aquel tribunal. De hecho, a pesar de su condición, Español era el único notario que se encontraba en activo en el Santo Oficio aragonés en ese momento El resto estaban ausentes o enfermos y él se encontraba solo frente a todo el trabajo que se acumularía en el secreto. Su responsabilidad era tremenda y, sin embargo, servía el oficio sin recibir ninguna remuneración a cambio:

Gil Español de Niño, secretario del Santo Officio de la Inquisición de Aragón, supplicando humilmente a Vuestra Alteza, dize que ha dos años sirbe su officio de secretario del secreto sin salario, gaxes, ni hemolumentos algunos, y con tanta pun-

Los inquisidores sabían que podían sacar provecho de Vicente Salvador en varios sentidos y justificaban su petición de la secretaría honoraria ante la Suprema aduciendo que se le podría encargar de varias dependencias que ocurren por el distrito, las quales a vezes no pueden tener el curso que se necessita por la falta que nos hacen los secretarios dentro del secreto (AHN, Inquisición, Legajo 504, expediente 1, fol. 245v).

La Inquisición de Valencia, por tanto, distinguía entre la figura del secretario "supernumerario” y la del "honorario”, siendo esta última condición la que se solicitó para el ya mencionado Vicente Salvador en 1741. Precisamente por esto, sorprende el hecho de que, en 1784, los inquisidores de aquel tribunal refiriesen a la Suprema cómo en aquel distrito, atendiendo a las noticias que constaban en el secreto, siempre se había estado en contra de ese tipo de designaciones. Incluso admitían que, en el pasado, se había conseguido que los peticionarios abandonasen su pretensión “invitándoles” a ello con presiones de diferente índole:

Illustrísimo Señor:

En cumplimiento de la orden de Vuestra Illustrísima de 31 del pasado, en que se ha servido Vuestra Illustrísima mandarnos incluir copia del memorial presentado por el doctor don Antonio Josef Sarrión, presbítero, vezino de esta ciudad, notario de este Santo Ofizio y al presente rezidente en esa Corte, por el que solizita que Vuestra Illustrísima se sirva hacerle la gracia del distintivo y honores de secretario de este tribunal, previniéndonos que sobre esta ystancia informemos a Vuestra Illustrísima con nuestro parezer, debemos decir que en este tribunal no hay memoria que en tiempo alguno haya havido secretario ninguno honorario, teniéndose positivas noticias de que, haviendo intentado algunos sujetos solizitar semejantes gracias, por el mismo tribunal se les ha hecho saber confidencialmente desistiesen de su pensamiento, porque se vería en la precisión de informar en contrario si, como era regular, se mandaba informar como en el caso presente. Por lo qual nos pareze que en esta parte podría tener muchos inconvenientes el hacerse novedad (AHN, Inquisición, Legajo 504, expediente 2, fols. 187v-188r).

En 1816, este mismo tribunal será el que recomiende que, si en la Suprema se concede una secretaría del secreto a don Eugenio Jordá y Furió, algo a lo que los inquisidores se oponían, sea por lo menos "honoraria” y no titular (AHN, Inquisición, Legajo 504, expediente 4, fols.122v$123 \mathrm{v})$. 


\section{BÁRBARA SANTIAGO MEDINA \\ EN LO PROFUNDO DE LA FRÁGIL MEMORIA: LOS “OTROS” SECRETARIOS DEL SANTO OFICIO}

tualidad como si los tubiera, y a sido forçoso el acudir a serbir por estar ausentes los secretarios Ciberio y Messa mucho tiempo, y alguno de ellos más de un año. Y el secretario Juan Ochoa de Çárate, emfermo muchos días. Y ahora el secretario Domingo Forcada ha sorteado en consejero de Çaragoza y habrá de haçer algunos días falta al tribunal. Y Gil Español continúa assistencia, por lo qual supplica a Vuestra Alteza le haga gracia y merced de que se le señale la aiuda de costa que a Vuestra Alteza pareziere para que pueda servir con la puntualidad y cuidado que oy, hasta que entre en propiedad de secretaría, que será hacelle Vuestra Alteza muy particular gracia, fabor y merced ${ }^{5}$.

El texto anterior resulta interesante por varios motivos. Uno de ellos se debe a que refleja cómo, a veces, los secretarios supernumerarios podían asumir las tareas y obligaciones de sus compañeros “del número”, aunque sin llegar a tener sus atribuciones. Pero, quizás, uno de los aspectos más relevantes del texto se encuentre al final del mismo. Tal y como se desprende de la petición, Gil Español de Niño espera, en algún momento, poder acceder a la secretaría “en propiedad”. De manera que, al igual que sucedía con las ayudantías, las secretarías supernumerarias se consideraban un "puente" hacia el oficio de secretario del secreto, una forma de hacer méritos para alcanzar un fin muy concreto: escalar dentro de la institución inquisitorial. El problema es que, como también puede verse en el caso de Gil Español de Niño, esa especie de situación transitoria podía prolongarse durante años, y nada aseguraba que, finalmente, el objetivo llegara a alcanzarse. En 1632, uno de los secretarios zaragozanos antes mencionados, Martín de Ciberio, falleció. Los inquisidores del tribunal, entonces, refirieron a la Suprema que, en aquel momento, había cinco notarios del secreto, habiendo sido Ciberio el sexto. Un número que les parecía excesivo, pues pensaban que, solo con tres, la Inquisición estará muy suficientemente servida. No deja de resultar una paradoja el que afirmen que solo tres secretarios del secreto son "suficientes”, mientras había seis sirviendo “de número” y, al menos, un supernumerario, supuestamente por la cantidad de trabajo que había en las oficinas del Santo Oficio. Sin percibir salario, por lo menos Español de Niño había conseguido que el Inquisidor General le permitiese recibir ayudas de costa como a sus compañeros, lo que remediaría en parte su situación ${ }^{6}$. Los inquisidores, a la muerte de Ciberio, defendieron su candidatu-

\footnotetext{
${ }^{5}$ AHN, Inquisición, Libro 974, fol. 19r.

${ }^{6}$ En 1630, el Inquisidor General Zapata había concedido ayudas de costa al Tribunal de Zaragoza por las causas expedidas durante ese año. En el documento de concesión aparece un listado con todos los perceptores y la cantidad a recibir. Los secretarios que constan en él son: Juan Ochoa de Zárate, Martín de Ciberio, Domingo Forcada, Sebastián de Lezaún y Heredia, Francisco de Hermosa y Gil Español de Niño. Este último no aparece como supernumerario, sino entre el resto
} 


\section{Bárbara SANTIAgo MEdina \\ EN LO PROFUNDO DE LA FRÁGIL MEMORIA: LOS “OTROS” SECRETARIOS DEL SANTO OFICIO}

ra, pero no debe olvidarse cómo, a la vez, pensaban que tantos secretarios eran demasiados. Pero, si el Inquisidor General veía la necesidad de cubrir la plaza de Ciberio, no dudaban en proponer a Gil Español de Niño, así por su calidad y serviçios, como por sus buenas partes ${ }^{7}$.

Español de Niño nada sabía de la opinión de los inquisidores cuando, por su parte, se apresuró a escribir solicitando la plaza de secretario del secreto inmediatamente después de fallecer Martín de Ciberio. Gracias a su documento, y también al del tribunal, es posible saber que sus circunstancias dentro del secreto eran un tanto “especiales”, principalmente porque, cuando se le nombró supernumerario, por orden directa del rey, fue con la condición de obtener la primera plaza de secretario titular que quedase vacante. Un hecho que ahora, después de cinco años de servicio prácticamente gratuito en el tribunal, por fin se producía:

Gil Español de Niño, notario del secreto del Santo Officio de la Inquisición de Aragón, diçe que Su Magestad fue servido (atendiendo a sus muchos servicios hechos al Santo Officio por sí y sus anteçesores, y en particular en las Cortes de Aragón), mandar por sus reales decretos se le diese título de notario del secreto de aquella Inquisición con exerciçio desde luego. Y que en la primera vacante entrase a servir en propiedad. Y en su cumplimiento Vuestra Alteza mandó se le despachase título de ello y que començase a servir el dicho officio, el qual a más de çinco años que exerçe con la puntualidad y satisfación que es notorio, sin aver llevado en todo el dicho tiempo salario ni emolumento alguno, ni más que la ayuda de costa ordinaria destos dos últimos años. Y, porque ahora a vacado la dicha plaza de notario del secreto en propiedad, por muerte de Martín de Zeberio, pide y supplica a Vuestra Alteza sea servido hazerle merced se le dé el salario que el dicho secretario Çeberio tenía y que entre en propiedad en el dicho officio, conforme a los dichos decretos de Su Magestad, que en ello reçivirá muy gran merçed ${ }^{8}$.

Sin embargo, sorprendentemente, apenas dos días después de escribir a la Suprema mostrando cuál era su postura al respecto de Español de Niño, enviaron un nuevo documento por el que elevaban una petición muy concreta. En definitiva, solicitaban que, a medida que fueran vacando las secretarías del secreto, éstas

de secretarios del secreto. Todos ellos recibieron una ayuda de costa de 20.000 maravedís por su trabajo (AHN, Inquisición, Libro 975, fol. 87r).

En lo que respecta solo a Español de Niño, el mismo Inquisidor General había dispuesto:

He tenido por bien, en consideración de los buenos serviçios que Gil Español de Niño, secretario del secreto de ese tribunal, haze en él de algunos años a esta parte, gane la ayuda de costa que los demás secretarios del dicho tribunal, aunque éste sirbe sin salario alguno y así he mandado le pongan en el repartimiento que ba hecho de la ayuda de costa ordinaria deste presente año. Y ordenaréis, señores, al receptor se la pague y al contador se la pase en cuenta (AHN, Inquisición, Libro 975, fol. 92r).

${ }^{7}$ AHN, Inquisición, Libro 974, fol. 891r.

${ }^{8}$ AHN, Inquisición, Libro 974, fol. 892r. 
se fuesen suprimiendo de manera sucesiva hasta que solo quedasen tres secretarios. De nuevo, insistieron en que, según su criterio, tres eran suficientes. Además, esta medida supondría un alivio para la hacienda del tribunal, pues le falta a esta Inquisición lo necesario para los gastos ordinarios ${ }^{9}$.

No parece que le concedieran la secretaría titular a Español de Niño, pero el Inquisidor General le favoreció con la prerrogativa de participar en los derechos que llevaban los demás secretarios del secreto. Como era de esperar, esto ocasionó una respuesta airada por parte de estos, quienes no veían al supernumerario como un igual y mucho menos aprobaban que se le concedieran ciertos privilegios. De hecho, ahora, de todos los secretarios, él era uno de los de mayor antigüedad en el oficio, lo que le situaba por encima de, al menos, otros dos. Esto, nuevamente, dada su categoría, no iba a ser aceptado por el resto de miembros del secreto. Uno de ellos, Sebastián de Lezaún y Heredia, en su nombre y en el de un enfermo Francisco de Heredia, redactó un esclarecedor documento en el que se ejemplifica a la perfección cuál era la opinión de estos secretarios respecto a los supernumerarios y, en concreto, sobre Español de Niño, quien, según ellos, prácticamente no tendría derecho ni al oficio que ostentaba, por haber sido el suyo un nombramiento "condicional” y "temporal":

Dicen que an presentado en dicho Santo Officio un memorial suplicando mandasen declarar los inquisidores que Gil Español, secretario supernumerario y estraordinario, no abía podido ni puede goçar, en perjuicio de los suplicantes, prebilegios de más antiguo y, por averse abstenido los inquisidores de haçer dicha declaraçión, remitiendo la resoluçión y determinaçión a Vuestra Alteza, representan por su parte y pretensión que los supplicantes son secretarios ordinarios, titulados y asalariados y del número de los quatro que acostumbrado haber y ai en dicho Santo Officio. Y como tales lleban y cobran el salario ordinario que está tasado y aplicado a dichos officios con los otros derechos, sin limitaçión alguna y pues que prefieren en esto al dicho Español, que es lo exençial, y lo que constituye en verdadera posesión del officio de secretario, lo an de preferir en las otras pretensiones. Demás que también la nominación de Gil Español fue mientras que una hija del secretario Francisco Rubalcaba tomase estado de matrimonio a quien Vuestra Alteza hiço graçia y merçed del officio que tubo el padre de aquella para su yerno. I aunque esta graçia no se verificó ni tubo efecto, se mandó a Gil Español que se abstubiese de entrar en el secreto, aunque después se le mandó continuase en el officio en la manera y forma que hasta entonçes y así su título fue y es condiçional y no perpetuo como el de los suplicantes, si vien todos sugetos al benepláçito y mera voluntad de Vuestra Alteza. Deçir también que Gil Español fue nombrado secretario supernumerario y extraordinario y que no entró por bacante de otro. I que su nombramiento fue sin salario, ni ayuda de costa, ni otro probecho, dándole solo título para servir y adquerir lo demás anejo al officio y entrar en alguna bacante y que después, por los ser-

${ }^{9}$ AHN, Inquisición, Libro 974, fol. 893r. 


\section{BÁrbara SANTIAGo MEdina \\ EN LO PROFUNDO DE LA FRÁGIL MEMORIA: LOS “OTROS” SECRETARIOS DEL SANTO OFICIO}

viçios de algunos años, se le mandó dar ayuda de costa, pero siempre ésta sin el salario, porque ai quatro ordinarios que lo reçiben y cobran ${ }^{10}$.

De igual modo, reclamaban su antigüedad, exigiendo que Gil Español no pudiese precederles en ningún acto protocolario. La respuesta de la Suprema fue tajante. No consideraba que Gil Español fuese un "supernumerario”, sino un secretario ordinario, por lo que habría que guardarle la antigüedad desde el día de su posesión, lo que le situaba por encima de Lezaún y sus compañeros. También se ordenaba el cese de la disputa:

Que la antigüedad se guarde a cada uno desde el día que tomó la posesión, advirtiéndoles a los notarios del secreto que no ay officios extraordinarios, ni supernumerarios, porque el señor Inquisidor General puede proveer todos los officios que fuere servido. $\mathrm{Y}$, asimesmo, se les advierta que se quieten y no turben la paz con novedades ${ }^{11}$.

Gil Español tenía derecho a réplica y no tardó en responder también a los secretarios, aduciendo que, cuando había recibido su título en 1627, en él se especificaba que, una vez hubiese realizado el juramento de fidelidad y secreto al que estaba obligado, los inquisidores aragoneses debían guardarle y hacerle guardar todas las gracias, franquezas y exemptiones, prerrogatibas y libertades y preheminençias que, por razón del dicho ofiçio y cargo hos deben ser guardadas y se acostumbran guardar, etc. También refería cómo los autores del escrito en su contra, Lezaún y Hermosa, habían tomado posesión de su oficio después que él y, por tanto, eran más “modernos”, debiendo él precederles en todos los actos públicos en los asientos ${ }^{12}$. Por tanto, suplicaba no ser privado de su antigüedad, ni de sus preeminencias, pues había llegado a ser el terçero secretario deste Santo Officio y sirbo con mucho amor y puntualidad y asta oy lo an tolerado los dichos Heredia y Hermossa ${ }^{13}$.

A pesar de la problemática generada con Gil Español, el Inquisidor General repitió la jugada y realizó otra vinculación a la secretaría del secreto idéntica a la de éste. Fue en 1634 y, el beneficiario, Domingo Casanova, yerno de Domingo Zorrilla, secretario de secuestros del tribunal. En principio, para que la familia no perdiese hacienda, se decretó que tomaría posesión de la primera secretaría del

${ }^{10}$ AHN, Inquisición, Libro 975, fols. 84r-v.

${ }^{11}$ AHN, Inquisición, Libro 975, fol. 82r.

12 Según su testimonio, tanto Sebastián de Lezaún y Heredia como Francisco de Hermosa habían accedido al oficio en 1629, es decir, dos años después de que lo hiciese él (AHN, Inquisición, Libro 975, fol. 88r).

${ }^{13}$ AHN, Inquisición, Libro 975, fol. 88v. 


\section{Bárbara SANTIAGo MEDiNa \\ EN LO PROFUNDO DE LA FRÁGIL MEMORIA: LOS “OTROS” SECRETARIOS DEL SANTO OFICIO}

secreto que quedase vacante a la muerte de su suegro. Sin embargo, en 1638, se le concedió un título similar al de Gil Español, lo que le convertía en secretario del secreto, pero sin ejercicio, a la espera de que esa vacante se produjese. Casanova también podría goçar de las preheminençias y exemptiones de dicho offiçio, de manera que una vez más se desató la ira del resto de secretarios del secreto, en especial porque pretendía concurrir en los actos y acompañamientos del tribunal como si ya hubiera entrado en el ofiçio, siendo esto contra los suplicantes y todos los ofiçiales, pues, no siéndolo hasta que llegue el caso, quiere concurrir con unos y preçeder a otros. Asimismo, insisten en que el número actual de secretarios, cinco, es suficiente para el trabajo que hay en el secreto ${ }^{14}$.

A Gil Español de Niño, como ya se ha visto, se le permitió participar en los derechos de la secretaría, al igual que los oficiales titulares de ella. Hoy no podríamos menos que decir: ¡qué menos! Pero, situaciones como ésta, solo se daban en momentos excepcionales y con personas muy concretas, habiendo de estar la concesión debidamente justificada. Aun así, no es raro que los supernumerarios elevasen súplicas y peticiones a sus inquisidores y a la Suprema, en busca de algún tipo de ayuda económica, dada la carga de trabajo que soportaban y que no cobraban nada por ello. Eso fue lo que hizo, en 1777, José Benito del Cerro, supernumerario de la Inquisición de Corte, al solicitar un salario de 1.000 maravedís anuales por su ocupación. De la misma forma que, hacía más de treinta años, se le había otorgado a otro secretario: el presbítero don Juan de Montiano y Sopelana ${ }^{15}$. La Suprema accedió a su petición ${ }^{16}$. Del Cerro solo llevaba tres años sirviendo el oficio, de manera que podía considerarse bastante afortunado por ello. Pero no hay que engañarse, quizás en estas concesiones tuviese algo que ver el hecho de que perteneciese a la Inquisición de Corte, tan vinculada al Consejo y no solo por su cercanía física.

El trabajo sin remuneración, solo por placer, es una utopía de unos pocos. El supernumerario, como ya se ha expuesto, siempre debía tener en mente el objetivo de hacerse con el título que le habilitaría como oficial del número y, por tanto, con todos sus beneficios y prebendas. Era una carrera de obstáculos, pues, al fin y al cabo, la meta podría llegar o no. Y, a veces, solo llegaba tras largos años de trabajo a cambio de nada. Los inquisidores de distrito eran más conscientes de la des-

\footnotetext{
${ }^{14}$ AHN, Inquisición, Libro 976, fol. 158r-159v.

${ }^{15}$ AHN, Inquisición, Legajo 4.415.

${ }^{16}$ En atención a los méritos y continuos servicios del contenido don Josef Benito del Cerro y a lo que sobre ello le ha expuesto el tribunal, hace la gracia y concede mil maravedís de sueldo anual sobre la receptoría del tribunal (AHN, Inquisición, Legajo 4.415).
} 
moralización que podía aquejar a estos colaboradores de la institución e, incluso, de su irritación. Esta es la causa de que, en ciertos momentos, defendiesen el pago de cierta cantidad de dinero por sus servicios, aunque fuese escasa. El beneficio era, nuevamente, doble. Por un lado, los supernumerarios se verían recompensados; por otro, se evitaría la ruptura de su vínculo con el Santo Oficio, de manera unilateral, si su situación llegaba a ser insostenible. Se trataba, en definitiva, de aumentar la moral de estos colaboradores para que no abandonasen la institución. No es extraño, entonces, que en los informes que los distritos enviaban a la Suprema sobre estos individuos, una de las razones que suelan aparecer en los mismos para mostrar su apoyo a la pretensión a la que se aspiraba era la de que, el pago del salario o la ayuda extraordinaria que se solicitaba, sería para los supernumerarios de nuevo estímulo para maior cumplimiento de su obligazión ${ }^{17}$.

Las secretarías supernumerarias, en principio sin coste aparente para el Santo Oficio, fueron una importante baza con la que jugar a la hora de aumentar el prestigio de la institución. Siempre deseosa de atraer a sus filas a miembros de estamentos privilegiados de la sociedad, este oficio acabó convertido más en una suerte de puesto honorífico, que en un empleo propiamente dicho, aun cuando los títulos fuesen expedidos con la indicación expresa de que el oficio sería con "ejercicio" en el secreto. Nuevamente, la habilidad administrativa de los hombres que optaban a estas secretarías debía ser relativa y, sin duda, tampoco estarían dispuestos a desempeñar la ardua labor que suponía ser un notario del secreto. Esto se hace especialmente manifiesto en el supuesto de personas que, además, compaginaban varios cargos, aunque fuesen solo de carácter representativo. Pertenecer al Santo Oficio era una dignidad más y, como tal, era buscada por determinados individuos para completar su cursus honorum particular. En muchos casos, la secretaría supernumeraria se concedía como una especie de premio de consolación, al no haber ninguna vacante disponible entre los notarios del número.

Otros, por el contrario, aspiraban directamente a uno de estos puestos supernumerarios, movidos precisamente por ese afán de conseguir una mayor notoriedad social, una realidad que, en el siglo XVIII, empieza a tener cada vez más presencia entre los miembros del Santo Oficio, aunque algunos tribunales parecen más proclives a ella. En 1777, por ejemplo, solicitó el puesto de secretario supernumerario de la Inquisición de Corte don José Martínez de Viergol, ayuda de los furriera del Príncipe, nuestro señor, thesorero de su Real Bolsillo Secreto y con ausencias y enfermedades de thesorero de la Princesa, nuestra señora. Menos de

\footnotetext{
${ }^{17}$ AHN, Inquisición, Legajo 4.415.
} 
una semana más tarde, el Inquisidor General ya le había concedido el oficio, sin tan siquiera esperar al resultado de las pruebas de limpieza de sangre. Exactamente siete días después de esta concesión, se le otorga la gracia de hacer las pruebas y la de espera de dos años para que le sean hechas a su esposa, doña Luisa de Barrio ${ }^{18}$.

Un año más tarde, en 1778, será el Marqués de Grimaldo, don Bernardo María Grimaldo, quien muestre interés por una secretaría supernumeraria en el Tribunal de Corte. Según la petición elevada al Inquisidor General, sus antepasados siempre habían estado muy ligados al Santo Oficio y él quería seguir su ejemplo. Observando sus cargos y honores, no es difícil deducir cómo dicha secretaría solo sería uno más entre ellos. La falta de remuneración no era, en ningún caso, un problema para estos candidatos que gozaban de un importante respaldo económico y social:

Don Bernardo María de Grimaldo, Marqués de Grimaldo, Cavallero del Orden de Santiago, Comendador de Rivera y Azeuchal de la misma orden, Canciller Mayor de la Insigne Orden del Toisón de Oro, del Consejo de Su Majestad en el de Flandes, Rexidor Perpetuo de la ciudad de San Phelipe, gentilhombre de cámara de Su Majestad, con entrada, theniente de la Real Compañía de Alabarderos, Mariscal de Campo de los Reales Exércitos ${ }^{19}$.

Sin embargo, es necesario advertir cómo la creación de secretarías supernumerarias no siempre fue del agrado de todos, en especial de los compañeros del número, pues, si los supernumerarios trabajaban en el secreto y tenían acceso a la distribución de los derechos cobrados por las gestiones documentales, serían más personas a repartir y, por tanto, los ingresos de cada una serían menores ${ }^{20}$. Si antes se ha visto la problemática de Gil Español cuando éste solicitó la plaza del fallecido Martín de Ciberio, ahora es momento de añadir cómo ése no fue el primer des-

\footnotetext{
${ }^{18}$ AHN, Inquisición, Legajo 4.415.

${ }^{19}$ AHN, Inquisición, Legajo 4.415.

${ }^{20}$ Juan Antonio Llorente se mostraba radicalmente contrario a la práctica de crear puestos supernumerarios y honoríficos:
}

Por ningún extremo considero del caso el nombrar secretarios supernumerarios con exercicio y menos secretarios honorarios. O hacen falta, o no, más secretarios que los del actual número: en el primer caso, aumentar el número: en el segundo son inútiles. Los más que quieren ser supernumerarios con exercicio, lo desean, por curiosidad de saber secretos o por eximirse de la jurisdición de los obispos, mejor que por trabajar con zelo del bien de la religión. Los honorarios no llevan otro objeto que el de la vanidad de condecorarle con la calificación de su linage; esto es contra los santos fines del instituto de la Inquisición y aquello contra su buen gobierno (Juan Antonio LLORENTE: Los procesos de la Inquisición: Discursos sobre el orden de procesar en los tribunales de la Inquisición, Pamplona: Eunate, 1995, p. 158). 
encuentro que tuvo con los secretarios del número. Los conflictos llegaron desde su mismo nombramiento.

Gil Español procedía de una familia de importante tradición inquisitorial. Él mismo era familiar y, según un memorial que presentó, con el que trataba de apoyar su solicitud de una secretaría supernumeraria en 1626, sus antepasados habían estado ligados a la institución desde que el propio rey Fernando el Católico había establecido el tribunal en el Reino de Aragón. No en vano entre sus ascendientes había familiares, comisarios y hasta uno de sus primos había fallecido siendo inquisidor en Sicilia (Miguel Español de Niño) ${ }^{21}$. Los secretarios del secreto, por aquel entonces Juan Ochoa de Zárate, Pedro Jerónimo Bonet y Martín de Ciberio (a quienes habría que añadir un cuarto que no se menciona), se mostraron radicalmente en contra de la petición, ya que, por un lado, veían peligrar su economía y, por otro, lo consideraban un agravio personal tras tantos años de servicio. En resumidas cuentas, se oponían a los nombramientos de supernumerarios, en virtud de lo anterior, y a que los asuntos que en aquel momento se trataban en el secreto no eran los suficientes como para justificarlos. Y a ello se añadía que el receptor tenía un permiso expreso del Inquisidor General que le facultaba para entrar en el secreto siempre que los secretarios necesitasen ayuda en su trabajo. Merece la pena reproducir íntegro el documento enviado por los titulares de la secretaría a los inquisidores del Santo Oficio de Zaragoza para poder seguir, uno por uno, sus razonamientos:

Juan Ochoa de Çárate, don Pedro Gerónimo Bonet y Martín de Çeberio, secretarios del Santo Ofiçio de la Inquisición del Reyno de Aragón, diçen que Gil Español de Niño, familiar de dicho Santo Ofiçio, y otros, valiéndose de decretos del Rey, nuestro señor, y otros medios, pretenden ser secretarios supernumerarios de dicha Inquisición, aviendo quatro del secreto y uno de secrestos, que es ofiçio muy desocupado para poder ayudar si fuera nesçesario. Y en caso que lo sea, tiene Vuestra Alteza mandado que el reçeptor que de presente es, por aver sido secretario y persona intiligente, pueda entrar en el secreto y ayudar a dichos secretarios. Y aviendo al presente tan pocos negocios como ay que trabajar en el secreto, porque succede no aver más de dos o tres presos en las cárçeles y este año a habido muchos meses sin ninguno. Y porque dicha Inquisición está muy corta y pobre de hazienda, de suerte que, en no arrendándose los canonicatos, no avrá de qué pagar los salarios. Y, de poner secretarios supernumerarios, sería al dicho Santo Ofiçio de muy gran perjuiçio, por quanto al fin del año pedirían ayuda de costa y, a los secretarios susodichos, se les seguiría muy gran daño y menoscabo de los derechos que tienen, a más de su salario, que mucha parte dél han menester para alquiler de casa, demás que los mantenimientos y demás cosas se han encareçido, de suerte que tienen nesçesidad de valerse de otra hazienda para poderse tratar y sustentar con el luzimiento y

${ }^{21}$ AHN, Inquisición, Libro 973, fol. 394r. 


\section{BÁRBARA SANTIAGO MEDINA \\ EN LO PROFUNDO DE LA FRÁGIL MEMORIA: LOS “OTROS” SECRETARIOS DEL SANTO OFICIO}

decoro que requieren dichos ofiçios. Y no sería justo que, al cabo de tantos años que ha que sirben con la rectitud, puntualidad y cuidado que es notorio, se les disminuyese lo que hasta agora han tenido de sus derechos y probechos. Por lo qual suplican a Vuestra Alteza se sirba de mandar no dar lugar a cosa de tanto perjuiçio para los suplicantes, pues de lo contrario se podrían seguir algunos inconvenientes y inquietudes que, hasta agora, no ha habido en raçón de exerçer rectamente dichos sus oficios. Y, siendo nesçesario, suplican a Vuestra Alteza de que el Tribunal deste Santo Oficio informe de todo lo susodicho, que en ello esperan resçibir merçed de Vuestra Alteza como siempre, pues los que pretenden no tienen serbicios vastantes y pueden aguardar a que Vuestra Alteza les haga merçed de vacantes que se ofrecieren $^{22}$.

Los inquisidores, por su parte, no podían estar más de acuerdo con todo lo expuesto por los secretarios. No querían supernumerarios en el tribunal. Sus motivos, además de los presentados por Ochoa, Bonet y Ciberio, eran que este tipo de nombramientos, en su opinión, generaban ciertos conflictos internos y, asimismo, podían poner en peligro la integridad del propio Santo Oficio de Zaragoza violando el secreto, pues la mayor parte de los solicitantes, incluido Gil Español de Niño, eran naturales del propio Reino de Aragón $^{23}$. Esta última consideración, muy arraigada entre los inquisidores zaragozanos, se repetirá en múltiples ocasiones. Según su criterio, los aragoneses trataban de boicotear el Santo Oficio en su territorio por todos los medios, de manera que habría que limitar su acceso a la institución, cubriendo sus puestos con personas de fuera del reino.

De nada sirvieron las quejas de los secretarios ni los argumentos del tribunal. El Inquisidor General concedió la secretaría supernumeraria a Gil Español, con derecho a ocupar la primera plaza del número que vacase en Zaragoza. No cobraría salario ni emolumentos por ello, al menos hasta que accediese a una plaza de titular ${ }^{24}$. La historia posterior es ya conocida, por cuanto se ha expuesto con anterioridad.

Los tribunales de distrito utilizaban los puestos supernumerarios, tanto de oficiales, como de ministros, en sus juegos de poder y para cubrir ciertas necesidades administrativas. Si se quería conseguir el favor de cierta élite local y con ello aumentar el prestigio de la institución, se nombraba a uno de sus miembros oficial supernumerario del tribunal y todo quedaba resuelto. De igual modo sucedía cuando se querían hacer vinculaciones y herencias endogámicas, traspasando un oficio o ministerio entre miembros de la misma familia, o cuando surgían ciertas necesidades administrativas. En caso de urgir más manos en el secreto, se re-

\footnotetext{
${ }^{22}$ AHN, Inquisición, Libro 973, fols. 395r-v.

${ }^{23}$ AHN, Inquisición, Libro 973, fols. 393r-v.

${ }^{24}$ AHN, Inquisición, Libro 973, fol. 399r.
} 
curría a estos supernumerarios, que no siempre cobraban por su trabajo, como sucedía a veces con los ayudantes, escribientes o notarios contratados. Eran, al fin y al cabo, un recurso fácil empleado por los tribunales en su propio beneficio. Pero, como queda referido, su figura no estuvo exenta de cierta problemática. Los inquisidores se aprovechaban de la situación y, en una relación de absoluta simbiosis, los beneficiarios de estos oficios, también. $\mathrm{O}$ al menos así era hasta que las ventajas se tornaban en desventajas. Los supernumerarios, en definitiva, estaban en cierto modo vinculados a los oficios titulados y, como no podía ser de otra forma, aspiraban en algún momento a desempeñarlos. Si el tribunal abusaba de su prerrogativa y, en connivencia con la Suprema, se excedía en el número de supernumerarios, tanto en oficialías, como en ministerios, no todos ellos podrían llegar a formar parte de los tribunales como miembros de pleno derecho, con todos los honores y gracias que esto conllevaba. Simplemente, no existirían tantos oficios titulados como personas que, en calidad de supernumerarias, estaban vinculadas a ellos. Esto ponía en aprietos a los tribunales, ya que se encontraban “obligados” hacia ellas, pero no siempre contaban con los recursos económicos como para mantener un cierto número de oficiales y no es extraño que, en algunos casos, los distritos solicitasen incluso la supresión de algunos oficios según estos fuesen vacando, en vista de que tenían dificultades para acometer el pago de los salarios. Por ello, ciertos individuos se quedaban a las puertas de alcanzar su objetivo y, como era de esperar, se generaba un importante malestar entre ellos. Algunos incluso habían realizado pruebas de limpieza para alcanzar el grado de oficial, abonando importantes cantidades de dinero por ellas, y, a pesar de haberlas aprobado, finalmente, se daban cuenta de que no iban a servir para nada.

En vista de estas circunstancias y de que las quejas de los afectados llegaban al Consejo, sus integrantes, en marzo de 1631, solicitaron al Inquisidor General, entonces Antonio Zapata y Cisneros, que no permitiese conceder más oficios ni ministerios con carácter supernumerario. Y, si vacase alguna plaza, que no la proveyese en nadie a menos que los supernumerarios existentes fuesen siendo "acomodados”. Por otro lado, también le suplicaron que en los officios de calificadores, comissarios, familiares y notarios, mande no se exceda del número que disponen las concordias y cartas acordadas, con que se obiarán los conocidos daños que resultan ${ }^{25}$. El hecho de que, meses después, en agosto del mismo año, los consejeros de la Suprema insistiesen sobre el tema, parece indicar que el Inquisi-

\footnotetext{
${ }^{25}$ AHN, Inquisición, Libro 373, fol. 75r.
} 
dor General no tenía una opinión coincidente con la de ellos ${ }^{26}$. De igual manera, tampoco parece que los tribunales empezasen a limitar el número de sus supernumerarios, con lo que la problemática siguió existiendo en el seno de la institución, procurando beneficiar a unos, pero perjudicando a otros.

$\mathrm{Al}$ margen de lo anterior, hay que referir la forma en que se han localizado también nombramientos de secretarios calificados en la documentación como "ad honorem". Si bien los supernumerarios y los honoríficos solían vincularse a un tribunal y desempeñar su labor en él, los ejemplos analizados de títulos otorgados "ad honorem” eran sutilmente diferentes a los de los anteriores. Las semejanzas venían marcadas porque se trataba de secretarios del secreto, también honorarios y pertenecientes a un tribunal concreto. Sin embargo, se distinguían porque eran nombrados para asistir en el Despacho del Santo Oficio de Corte o, lo que es más sorprendente, allí donde ellos deseasen o fuesen enviados por el Inquisidor General, la Suprema o sus superiores en el tribunal, a cumplir ciertos cometidos. Uno de estos títulos fue el de Domingo Ortiz de Azcárraga para el Tribunal de Cerdeña en Sacer en septiembre de $1643^{27}$. Fue nombrado por Antonio de Sotomayor, al igual que Pedro Noguerido Figueroa, que lo fue en noviembre del mismo año. Su distrito de referencia sería el de Cataluña, la sede del cual estaba en Barcelona, pero, nuevamente, estaría destinado en el Despacho de Corte y en las demás partes que quisiéredes para en los casos y negozios que por nos o por los inquisidores apostólicos de la dicha Inquisición se os cometieren ${ }^{28}$.

Los secretarios “ad honorem”, al igual que sus semejantes en el secreto, debido precisamente a esa cualidad de honorarios, no percibían ningún tipo de remuneración económica por su oficio. El beneficio social generado por su nombramiento ya es otra historia...

\subsection{Los ayudantes del Secreto}

La figura de los “ayudantes”, en concreto, puede localizarse en fechas muy tempranas, ya en el siglo XVI, y su misión no era otra que la de auxiliar a los secretarios titulados en su oficio. Pero no tenían sus atribuciones y, muchas veces, ni siquiera eran remunerados, al menos de manera “oficial”. No podían validar la documentación, una labor que realizaban los secretarios, y su trabajo parece haber quedado relegado al de meros escribientes que librarían a los mencionados secre-

\footnotetext{
${ }^{26}$ AHN, Inquisición, Libro 373, fols. 76r-v.

${ }^{27}$ AHN, Inquisición, Libro 364, fol. 13v.

${ }^{28}$ AHN, Inquisición, Libro 364, fol. 15r.
} 


\section{BÁRBARA SANTIAGO MEDINA \\ EN LO PROFUNDO DE LA FRÁGIL MEMORIA: LOS “OTROS” SECRETARIOS DEL SANTO OFICIO}

tarios de labores rutinarias, pero que a la vez agilizarían los asuntos del tribunal. Su intervención en la factura de los documentos resuelve la duda generada al ver cómo, textos validados por secretarios del secreto, estaban redactados con grafías que no se correspondían con las de estos. Sin embargo, por desgracia, su identidad suele permanecer en el anonimato, a menos que se consiga localizar alguna información sobre ellos, principalmente rastreando los indicios que se conservan en las cuentas de receptoría, la correspondencia de los tribunales o los registros del Consejo. Y, aun así, de la mayor parte de ellos no llegará a tenerse ninguna noticia, por lo que es difícil llegar a tener una idea de cuántas personas había realmente trabajando en el secreto a la vez, además de los propios secretarios titulados.

En un principio, las Instrucciones exigían que los oficiales desempeñasen sus oficios de por sí, sin que pudieran delegarlos en otra persona, pero, con el tiempo, muchas de las tareas diarias del tribunal terminaron por desbordar a sus miembros y abrieron la puerta a que se contase con colaboradores que aliviasen su situación. Pero, casi siempre al límite de su capacidad económica, la Inquisición no contaba con fondos suficientes como para remunerarles con un salario por sus actividades. De hecho, el salario de los mismos oficiales ya era lo suficientemente precario como para dificultar su subsistencia. Se necesitaban, en definitiva, ayudantes que sirviesen bien y de manera económica, que trabajasen sin la esperanza de una remuneración. Ante esta perspectiva, sin duda los únicos atractivos para desempeñar esta labor eran, por un lado, la propia vinculación con la institución inquisitorial, aunque ésta no fuese de pleno derecho; y, por otro, la promesa o el sueño de, quizás en un futuro, llegar a ocupar una de las plazas de secretaría, de alcanzar un título de oficial. Por ello no es raro que algunas de estas ayudantías fuesen desempeñadas por hijos u otros familiares de los secretarios en activo, de manera que se trataba de lograr una cierta vinculación endogámica con el oficio, que se transmitía entre miembros de una misma familia durante generaciones.

Como ya se ha mencionado, no siempre los ayudantes percibían una remuneración por su trabajo, pero, cuando lo hacían, un buen lugar para localizar datos sobre ellos suelen ser las cuentas de receptoría, en tanto que en ellas quedaban anotados los pagos que se les realizaban, con la indicación de la fecha y la cuantía de los mismos. Pero, en ocasiones, el dinero no se concedía directamente al ayudante en cuestión, sino al oficial con el que iba a colaborar. Así, existen ejemplos de incrementos salariales temporales concedidos con la única finalidad de que la cantidad suplementaria se destinase a la “contratación” de un ayudante. Este fenómeno no era exclusivo de los notarios del secreto, sino que también se dio entre otros tipos de notarios inquisitoriales, como fue el caso de los de secuestros, que, 


\section{Bárbara SANTIAGo MEdiNa \\ EN LO PROFUNDO DE LA FRÁGIL MEMORIA: LOS “OTROS” SECRETARIOS DEL SANTO OFICIO}

en algunos momentos, también manejaban un importante volumen de documentación. En febrero de 1561, por ejemplo, el Inquisidor General Fernando de Valdés otorgó 10.000 maravedís anuales a Juan de Guinea, notario de secuestros del Santo Oficio de Cuenca, con los que costearse un escriviente que le ayude a exercer su cargo, atento que ha mucho tiempo que sirve y que, con su mucha hedad, no puede dar a todo el rrecabdo necesario. De hecho, según parece, Guinea ya hacía tiempo que contaba con una persona que le ayudaba con el beneplácito de los inquisidores conquenses y de la Suprema ${ }^{29}$. Sin embargo, fue el mismo Valdés quien, en julio de 1566, nombró mediante una provisión un ayudante para el notario de secuestros de la Inquisición de Murcia ${ }^{30}$. Lo sorprendente en este caso no es el nombramiento en sí, sino que con éste se le concedía un salario anual de 25.000 maravedís, hecho que resulta del todo excepcional, pues la retribución anual de un secretario del secreto era, por aquel entonces, de 30.000 maravedís.

Pero Guinea fue afortunado. En 1575, su sucesor en el oficio de notario de secuestros en Cuenca, un Lope de Ungo de Velasco tan mayor que apenas podía cumplir sus funciones y con graves apuros económicos, pedía la misma ayuda que había tenido Juan de Guinea en el pasado. Éste había fallecido en 1564 y, desde entonces, Lope de Ungo no había pedido nada, pero ahora se veía en la necesidad de hacerlo, con una salud quebrantada, una mujer enferma y pocos recursos para su subsistencia y costear los gastos de su oficio ${ }^{31}$. Uno de los inquisidores conquenses, La Madriz, mostró su apoyo al secretario, pero su solicitud no fue aprobada en la Suprema, denegándosele los 10.000 maravedís que le hubiesen permitido tener un ayudante que le liberase en parte de su carga de trabajo ${ }^{32}$.

Al igual que sucedía con la persona “contratada” por Juan de Guinea, lo más habitual es que ni tan siquiera se les considerase "ayudantes", sino que fuesen simplemente "escribientes”, utilizados en su mayor parte, al igual que los anteriores, para dar salida a grandes volúmenes documentales en momentos de especial carga de trabajo o en los que, tal vez, solo urgiese terminar cuanto antes. Una de

${ }^{29}$ Según somos ymformado, ha rrecebido para ello en su conpanía a Pedro de Murga, con acuerdo y vuluntad del Reverendo Liçençiado Camino, inquisidor, como se le cometió por el Consejo que se hiziese (AHN, Inquisición, Libro 575, fol. 793r).

${ }^{30}$ AHN, Inquisición, Libro 575, fol. 930v.

${ }^{31}$ Otrosí suplico a Vuestra Señoría Illustrísima que, atento los muchos años que a que sirvo y que estoi viexo y muy cansado, se me mande dar alguna cosa para aiuda a un escriviente para que me ayude a hazer los negocios de mi officio y otros que algunas vezes se me mandan hazer, pues se a dado y da en otras inquisiciones y se dava en la de Quenca a mi antecesor, como constará a Vuestra Señoría Illustrísima del traslado de la provisión de que hago presentación, y no avía más negocios que agora (AHN, Inquisición, Legajo 2.544, expediente 288).

${ }^{32}$ AHN, Inquisición, Legajo 2.544, expediente 288. 


\section{BÁRBARA SANTIAGO MEDINA \\ EN LO PROFUNDO DE LA FRÁGIL MEMORIA: LOS “OTROS” SECRETARIOS DEL SANTO OFICIO}

las épocas de mayor delirio laboral en la audiencia y el secreto se daba, sin duda, en los meses previos a la celebración de un auto de fe, cuando debía ponerse fin a buen número de causas. Cuantas más personas participasen en la celebración, en tanto que condenados o penitenciados, más lucimiento tendría ésta y mayor alcance público tendría la institución. Pero es frecuente que, en esta coyuntura, los secretarios del secreto titulados se vieran desbordados por la cantidad de trabajo que se iba acumulando en sus anaqueles. Estas personas debían ser de plena confianza y realizar, como requisito previo al desempeño de sus funciones, el juramento de mantener secreto cualquier asunto referente al Santo Oficio del que pudiesen tener conocimiento mientras colaboraban con la institución. Así hizo, en una fecha tan temprana como el año 1529, un individuo apellidado Mudarra, que actuó como escribano para el Tribunal de Toledo durante varios días. Contar con él fue obligatorio y necesario para abreviar los negoçios para se hazer auto ${ }^{33}$. Y no es raro que se acudiese a ministros del Santo Oficio para estos menesteres, de manera que todo quedaba dentro de la propia institución. En 1645-1649, un familiar de la Inquisición de Zaragoza, Juan Jaime Esporrín, estuvo trabajando para el tribunal, aunque en este caso concreto se menciona en la documentación que hacía las funciones de notario del secreto, ayudando al despacho por la falta con que nos hallamos de secretarios y las muchas causas que an ocurrido, de que dimos quenta a Vuestra Alteza ${ }^{34}$. Esporrín, por su labor, no percibía ningún tipo de remuneración en forma de salario, ni ayuda de costa y, según el testimonio de los inquisidores, ni tan siquiera cobraba muchos de los derechos a los que hubiese tenido acceso, igual que sus compañeros en el secreto ${ }^{35}$. Con el tiempo llegaría a ser contador del Tribunal de Zaragoza e incluso se le llegaron a conceder varias ayudas de costa, pero siempre con carácter extraordinario, no participando nunca de las anuales y ordinarias ${ }^{36}$. Con un salario exiguo como contador, siguió ayudando en el secreto durante varios años, hasta que empezó a ausentarse del mismo. Tal vez se percató de que el tribunal, en cierto modo, estaba aprovechándose de sus esfuerzos. Finalmente, intentaría alcanzar el oficio de secretario del secreto, un trabajo que conocía bien ${ }^{37}$. Pero no lo consiguió. Fallecería en diciembre de 1654 , siendo to-

\footnotetext{
${ }^{33}$ AHN, Inquisición, Legajo 494, expediente 1, fol. 93r.

${ }^{34}$ AHN, Inquisición, Libro 978, fol. 206r.

${ }^{35}$ AHN, Inquisición, Libro 978, fol. 205r.

${ }^{36}$ En 1653, tras una petición elevada a la Suprema y secundada por los inquisidores, le fue concedida una ayuda de costa extraordinaria de 50 ducados (AHN, Inquisición, Libro 980, fols.

${ }^{37}$ AHN, Inquisición, Libro 980, fol. 96r.
} 93r-v). 


\section{Bárbara SANTIAGo MEdina \\ EN LO PROFUNDO DE LA FRÁGIL MEMORIA: LOS “OTROS” SECRETARIOS DEL SANTO OFICIO}

davía contador de la Inquisición de Zaragoza ${ }^{38}$. Los inquisidores, en un escrito a la Suprema, refirieron estar desconsolados por haver perdido un ministro como éste, que era hombre de las buenas prendas que havía en esta çiudad y muy afecto a tribunal ${ }^{39}$.

En esos mismos años, la Inquisición de México, también con un importante volumen documental, contaba con el apoyo de la Casa Profesa de la Compañía de Jesús, la cual enviaba a varios de sus miembros a ayudar en las labores del secreto. Esta colaboración se constata a lo largo de la década de los años 40 del siglo XVII gracias a las cuentas de receptoría, pero es presumible que vendría de años anteriores y, después, se prolongaría en el tiempo. Aunque se ha mencionado con anterioridad que, normalmente, los ayudantes no tenían derecho a percibir remuneración por su trabajo, en el caso de estos jesuitas el pago se disimulaba en concepto de "limosnas" entregadas a la Casa Profesa a la que pertenecían. En 1643, por ejemplo, se entregaron 250 pesos a esta institución por la labor desempeñada por los padres Alonso Muñoz, Jerónimo Pérez, Alonso de Medina y Francisco de la Canal $^{40}$. Un año más tarde, en 1644, estos "religiosos ayudantes", como aparecen denominados en la documentación, generaron a su casa 245 pesos de beneficio, los mismos que costó una pipa de vino que se entregó como limosna. A ellos, ahora de manera personal, se les pagaron 100 pesos $^{41}$. Curiosamente, gracias a una entrada de las cuentas de receptoría de 1646, es posible saber que la retribución se realizaba a estos religiosos debido a que en la casa professa donde estaban, havía neçessidad por falta de limosnas bastanttes para su sustentto ${ }^{42}$. En 1647 hubo otros dos ayudantes externos, ajenos a la Compañía, a los que se remuneró con ochenta pesos ${ }^{43}$. Pero, un año más tarde, volvió a abonarse a la Casa Profesa una cantidad de dinero por enviar varios religiosos para colaborar en el

${ }^{38}$ AHN, Inquisición, Libro 980, fol. 112r.

${ }^{39}$ AHN, Inquisición, Libro 980, fol. 112r.

Su hijo, también llamado Juan Jaime Esporrín, a la muerte de su padre a finales de 1654 solicitó el oficio de contador que había desempeñado éste o cualquier otro en que pueda continuar el deseo de servir a tan santo tribunal (AHN, Inquisición, Libro 980, fol. 338r).

${ }^{40}$ AHN, Inquisición, Legajo 4.809, expediente 6, fol. 79r.

${ }^{41}$ En este caso los religiosos que habían trabajado en el secreto del Tribunal de México habían sido: Francisco de la Canal, Alonso de Medina, Jerónimo Pérez y Juan de la Plaza (AHN, Inquisición, Legajo 4.809, expediente 6, fol. 83v).

${ }^{42}$ En 1646 se había reducido el número de colaboradores jesuitas. De los cuatro anteriores se pasó a solo dos: Francisco de la Canal y Juan de la Plaza (AHN, Inquisición, Legajo 4.809, expediente 6, fol. 90r).

${ }^{43}$ Se trataba del licenciado don Francisco de Lobette y don Juan de Iturralde. El primero recibió cincuenta pesos y, el segundo, treinta (AHN, Inquisición, Legajo 4.809, expediente 6, fol. $94 \mathrm{v})$. 


\section{Bárbara SANTIAgo MEdina \\ EN LO PROFUNDO DE LA FRÁGIL MEMORIA: LOS “OTROS” SECRETARIOS DEL SANTO OFICIO}

secreto $^{44}$. En 1649, por el contrario, se recurrió a dos miembros de la Orden Benedictina ${ }^{45}$.

A veces se contaba también con notarios externos a la institución, aunque no precisamente para redactar documentos, sino para otros menesteres más específicos. En Toledo, también en 1529, se recurrió a uno de ellos, Alonso Pérez, para leer las sentencias en el auto que se hizo en XXII de julio de IUDXXIX años ${ }^{46}$. En otros casos, en especial en estos primeros tiempos del Santo Oficio, también se consideró oportuno contar con la colaboración de notarios, ya que se presuponía su saber hacer en materia administrativa y documental. Así, el Inquisidor General Alonso Manrique de Lara autorizó al Tribunal de Valencia, ante una ausencia de secretarios del secreto, que estaban dedicados temporalmente a otros menesteres fuera de la sede, a contratar los servicios de un notario de confiança para entender en las cosas del secreto, a quien se le pagarían sus trabajos como es razón ${ }^{47}$. El proceso de selección era, por aquel entonces, mucho más relajado de lo que lo sería después, gozando los inquisidores de los distritos de gran autonomía.

Las ayudantías, como ya se ha mencionado, al igual que sucedía con los oficios supernumerarios, podían constituir un importante trampolín de acceso a la institución, aunque en ello intervenían multitud de factores. De hecho, se trataba de uno de los métodos de entrada más utilizado por las redes endogámicas de los tribunales de distrito. El procedimiento puede ser el siguiente. Un secretario numerario, por ejemplo, consigue que uno de sus hijos entre a trabajar en el secreto como ayudante, realizando labores de escribiente y otras tareas sencillas. Con el paso del tiempo, se tratará de dar el paso a la secretaría supernumeraria, con lo que la vinculación al oficio será más estrecha, teniendo, en algunos casos, concedida la merced de hacerse con la primera vacante que se produjese dentro de las secretarías titulares. Y, finalmente, después de años de servicio y quizás sin recibir ningún tipo de remuneración a cambio, se podría llegar a ser oficial titulado de un tribunal de distrito. Pero el número de plazas era exiguo, así que no todos los ayudantes conseguían avanzar en su cursus honorum de esta forma y muchos

\footnotetext{
${ }^{44}$ En este caso no se especifica quiénes eran los religiosos, pero su trabajo supuso un beneficio de 474 pesos a la Casa Profesa, siempre en concepto de "limosna”. El pago correspondía a 60 pesos por mes de ocupación (AHN, Inquisición, Legajo 4.809, expediente 6, fol. 98v).

${ }^{45}$ Veintte y quatro pessos a los padres fray Alonso Hortuño y fray Christóval Telles, del Orden de Señor Santo Domingo, en beintte y quatro de março de dicho año mill seisçienttos quarenta y nueve, por vía de limosna, por haver ayudado a escrivir en el secretto (AHN, Inquisición, Legajo 4.809, expediente 6, fol. 100r).

${ }^{46}$ AHN, Inquisición, Legajo 494, expediente 1, fol. 94r.

${ }^{47}$ AHN, Inquisición, Libro 319, fol. 211v.
} 
desistían por el camino, abandonando la carrera inquisitorial casi antes de que ésta se iniciase.

Antes de que estas redes endogámicas se afianzasen, las "sugerencias” para ayudantías también podían llegar desde las altas instancias de la institución. Cuando, en 1560, el Inquisidor General Valdés tuvo noticia de la necesidad de más manos que se tenía en el secreto del Tribunal de Valladolid, pues solo un secretario quedaba en el mismo para trabajar, propuso a los inquisidores una persona para actuar como “ayudante”. Primero debían investigarle para ver si resultaba apropiado y, en caso de no serlo, debían ser ellos quienes intentasen localizar a alguien adecuado para el puesto. En pocos documentos inquisitoriales podrá observarse tan claramente el concepto de "aprovecharse" de los ayudantes. De hecho, esa es precisamente la expresión que utiliza Valdés al final del texto:

Quanto a la neçesidad de escrivir que ay todavía de una persona que ayude en el secreto, entre tanto que vuelve Ybarguen, porque Landeta con estar solo no puede dar rrecabdo a todo lo que se ofrece, y ansí ha parecido a Su Señoría Reverendísima que vosotros, señores, os devéys ynformar de un mançebo que, por parte de su muger de Juan Alonso, se nonbró para casamiento. Si ay en él abilidad y suficiencia para poder ayudar en el secreto en esta necesidad. Y de su linpieza y costunbres. Pareciendo que lo podrá azer bien, le podréys admitir para entender en lo que aý se ofreciere. Y si en él ubiere algún ynpidimiento, procurad de buscar otro de quien tengáys satisfación y aprovechaos dél en el secreto ${ }^{48}$.

La mayor parte de estos ayudantes, al no recibir remuneración por su trabajo, se veían abocados a situaciones económicas precarias, a menos que contasen con un patrimonio personal que pudiese respaldar el dedicar una cantidad nada desdeñable de su tiempo al Santo Oficio y no a otros menesteres que pudiesen granjearles ingresos. Precisamente por ello, cuando llevaban ya años de servicio en el tribunal, algunos se atrevían a elevar una petición en busca de conseguir algún tipo de retribución. Como era de esperar, no se trata de solicitar salarios, ni ayudas de costa, a los cuales no tenían derecho por su posición dentro del tribunal, sino que se trataba de adquirir ganancias por otros medios ${ }^{49}$.

\footnotetext{
${ }^{48}$ AHN, inquisición, Legajo 575, fol. 152r.

${ }^{49}$ Circunstancias similares se encuentran también entre los secretarios supernumerarios. En 1774, Fernando Ciscar i Ciscar, que servía como supernumerario en Valencia, elevó una petición a los inquisidores para que, si se concedía la jubilación a uno de los titulares, percibiendo la mitad de salario, él se beneficiase de la otra mitad. Para ello alegaba que ha más de 5 años que sirve la referida secretaría, el primero de ellos sin haver tenido emolumento alguno, hasta que Vuestra Señoría Illustrísima se dignó de concederle los gages i que, empeñado ia en este destino, no puede dedicarse a otro, haviendo sufrido el gasto de mantenerse en esta ciudad no viviendo sus padres en ella, sin haver tenido otro producto que el de los gages, que es de mui corto ingreso (AHN, Inquisición, Legajo 504, expediente 2, fols. 52r-53r).
} 
Desde principios del siglo XVII, los secretarios del secreto de los tribunales de distrito tenía prohibido salir de las ciudades en que residían a hacer informaciones de limpieza. Esto disminuía sus ingresos, pues dejarían de percibir cantidades considerables en concepto de derechos, pero aseguraba su presencia en la sede del tribunal, donde era mucho más necesaria. Todavía les quedarían, sin embargo, aquellas pesquisas que se hiciesen en la propia ciudad desde donde se dirigía el distrito. Teniendo en cuenta esta disposición del Inquisidor General, algunos ayudantes clamaron por conseguir esa parcela de trabajo que había quedado libre, en manos solo de comisarios y notarios. Uno de ellos fue Nicolás del Río, hijo, a su vez, de Nicolás del Río, secretario del secreto de la Inquisición de Valencia. En 1609 llevaba ya varios años trabajando de ayudante en aquel tribunal, escribiendo y aprendiendo el oficio de la secretaría, pero sin cobrar nada por ello. La familia vivía solo del salario de su padre, de manera que él deseaba participar en la economía familiar de alguna forma. Una posibilidad la suponían las informaciones de limpieza, por la que se cobraban derechos y dietas, pero estaban vetadas a los secretarios del secreto. Nicolás del Río suplicó a la Suprema se le permitiese salir a realizar las pruebas y otras diligencias cuando fuese necesario, alegando que él no era un oficial titulado y, como tal, no estaba comprendido en lo estipulado por el Inquisidor General:

He pedido algunas vezes a los dichos inquisidores me cometiesen algunos negocios de fuera, como son informaciones de limpieza, probanças y defensas en pleytos criminales entre partes, y me han respondido que no puedo salir a hazer los dichos negocios por comprehenderme la carta acordada de Vuestra Alteza que prohíben que salgan los notarios del secreto a hazer fuera informaciones de limpieza, no deviéndose esto entender conmigo, porque ni yo soy notario del secreto, ni llevo salario del fisco, ni ago más de entrar en el secreto y hazer lo que allí se me manda. $\mathrm{Ni}$ se les seguirá a las partes por salir yo a los dichos negocios más costa, porque no quiero que se me dé más dieta que la que llevan los notarios del districto, a quien hordinariamente se cometen, los quales, muchas vezes, por no estar tan práticos en el stilo como deven, yerran los negocios y les es a las partes de mucho inconveniente y de más costa, por haverse de hazer de dos vezes. Por tanto, a Vuestra Alteza pido y supplico me haga merçed, en recompensa del tiempo que he servido sin ayuda de costa, ni gratificación alguna, y de lo demás que en esta petición refiero, me den carta para que los inquisidores me acomoden en los negocios que allí se offrescen, con que me entretenga y de adonde saque algún aprovechamiento, que en ello rescivirá particular merçed de Vuestra Alteza ${ }^{50}$.

En la Suprema, en febrero de ese mismo año, se aceptó la salvedad que presentaba Nicolás del Río, así como su súplica, de manera que se le concedió lo que

\footnotetext{
${ }^{50}$ AHN, Inquisición, Legajo 506, caja 1, fols. 59r-v.
} 
pedía $^{51}$. En su caso todo salió como era de esperar. Era hijo de oficial y llevaba años trabajando en el tribunal sin percibir nada. Cuando, en 1610, su padre fue jubilado de la secretaría del secreto, él "heredó” el título, ocupando su lugar gracias a una merced concedida desde la Suprema. Nada, por otra parte, que no resultase más o menos habitual ${ }^{52}$.

\subsection{Sustituciones y refuerzos internos}

De una manera diferente a los anteriores, existían ciertas personas que poseían un título expedido por el inquisidor general y cuyo cometido era cubrir a otros oficiales mientras estos no pudiesen desempeñar sus funciones. Este tipo de funcionarios del Santo Oficio se identifican a través de sus documentos de nombramiento, en los cuales se especifica que reciben su título solo para las ausencias y enfermedades de los oficiales numerarios. Estas designaciones afectaban a cualquier tipo de puesto dentro del tribunal, salvo, quizás, al de los propios inquisidores y el fiscal, y, por supuesto, también servían para suplir a los secretarios, con independencia de que fuesen o no del secreto.

Como puede suponerse, el obtener un nombramiento de sustituto equivalía a quedar vinculado a la institución y, en definitiva, tener la posibilidad de llegar algún día a ocupar una de las tan deseadas plazas numerarias. En 1693, por ejemplo, el Inquisidor General Diego Sarmiento de Valladares, Obispo de Plasencia, nombró notario del juzgado de bienes confiscados del Santo Oficio de Córdoba, en ausencias y enfermedades, a Pedro Felipe de Vargas, hijo de quien estaba ya desempeñando el oficio titular: Juan Francisco de Vargas ${ }^{53}$. Sarmiento de Valladares justificaba el título en base a los buenos informes que he tenido de los servicios del padre y por la inteligencia y demás partes del hijo. Es decir, de nuevo se remuneraba la fidelidad a la institución concediendo la "herencia" del oficio ${ }^{54}$. Otro ejemplo. En 1717 fue nombrado receptor en ausencias y enfermedades Baltasar Albornoz, hijo de quien entonces estaba precisamente en la receptoría: Car-

${ }^{51}$ Por Nicolás del Río, hijo de Nicolás del Río, notario del secreto de esse Santo Officio, se a dado en Consejo la petición cuya copia será con ésta. $Y$, vista, ha parescido que, atento que el susodicho no es notario del secreto, sino tan solamente ayudante, paresce no tiene inconveniente pueda salir a hazer informaciones de limpieza (AHN, Inquisición, Legajo 506, caja 1, fol. 58r).

${ }^{52}$ AHN, Inquisición, Legajo 506, caja 1, fol. 122r.

${ }^{53}$ AHN, Inquisición, Libro 396, fols. 107v-108r.

${ }^{54}$ El titulo fue expedido en 1693, pero se había aprobado su concesión ya en 1692 (AHN, Inquisición, Libro 396, fol. 11v). 
los Albornoz ${ }^{55}$. Ambos estuvieron ejerciendo como receptores "promisquamente", en palabras de los propios inquisidores, hasta 1734, en que se apartó al padre definitivamente del oficio ${ }^{56}$.

En otras ocasiones, en caso de no existir ningún suplente, titulado como tal, y haber plazas vacantes sin cubrir o, simplemente, en ausencia de ciertos individuos, necesitándose a alguien que desarrolle su trabajo, el tribunal jugaba con los oficiales que tenía, moviéndolos de un puesto a otro o, incluso, haciéndoles compaginar varios de ellos a la vez. En 1626, por ejemplo, el notario del juzgado de la Inquisición de Zaragoza, Gabriel Martín, pidió a la Suprema algún tipo de retribución económica, pues, al mismo tiempo que había estado cumpliendo con sus funciones en la audiencia civil, le habían cometido ocuparse de la notaría de secuestros. En total estuvo en ella más de ocho meses, sin percibir más que su salario de 600 reales como secretario del juzgado. En definitiva, lo único que solicitaba era la parte proporcional de salario y ayudas de costa que hubiera percibido quien hubiese estado en posesión del oficio de notario de secuestros ${ }^{57}$. Los inquisidores apoyaron su petición y corroboraron que, además, en el juzgado había pocas causas pendientes, lo que limitaba los ingresos en concepto de derechos de Gabriel Martín $^{58}$. Por fortuna, el Inquisidor General fue de su misma opinión y se le concedió lo que demandaba ${ }^{59}$.

Ese mismo año y también en Zaragoza, en el mes de marzo, la falta de secretarios del secreto era acuciante. Uno de ellos, Francisco Rubalcaba, acababa de fallecer y, otros dos, se encontraban en las Cortes. Solo quedaba allí Juan Ochoa de Zárate y, por ello, los inquisidores habían optado porque el receptor sirviese también en el secreto de manera temporal, aprovechando que había sido secretario y conocía el oficio, pero necesitaban en permiso de la Suprema. Su propuesta fue aceptada y se decidió que el receptor acudiría a todo lo que fuere menester [...], así en esta ocasión, como en las demás que conviniere ${ }^{60}$.

Parece que el tribunal aragonés tenía, al menos en estas fechas, algunos problemas con la secretaría del secreto. Dos años más tarde, en febrero de 1628, se

${ }^{55}$ Carlos Albornoz había sido, desde 1698, secretario del secreto del tribunal. En 1705 consiguió el título de receptor del mismo, siendo nombrado por el Inquisidor General Vidal Marín (AHN, Inquisición, Legajo 504, expediente 1, fol. 284v).

${ }^{56}$ Carlos Albornoz falleció en noviembre de 1741 (AHN, Inquisición, Legajo 504, expediente 1 , fols. $248 \mathrm{v}-249 \mathrm{r}$ ).

${ }^{57}$ AHN, Inquisición, Libro 973, fol. 347r.

58 AHN, Inquisición, Libro 973, fol. 346r.

${ }^{59}$ AHN, Inquisición, Libro 973, fol. 346r.

${ }^{60}$ AHN, Inquisición, Libro 973, fol. 324r. 
produjo la ausencia de todos los notarios. Martín de Ciberio estaba visitando el Santo Oficio de Toledo, y sus compañeros, Domingo Forcada y Juan de Mendoza, tampoco se encontraban en el tribunal. Debió contarse entonces con el secretario de secuestros, Domingo Zorrilla, quien ya en el pasado había echado una mano en el secreto cuando había sido necesario. Ahora la situación era de nuevo extrema y, por ello, los inquisidores zaragozanos escribieron a la Suprema para conseguir un documento que autorizase a Zorrilla a entrar en el secreto. El Inquisidor General, como no podía ser de otro modo, accedió a la petición, disponiendo que, entre tanto que van los notarios del secreto que faltan o en ocasiones muy precisas, entre. Y no de otra manera ${ }^{61}$.

En 1651 volvieron a surgir ciertas dificultades en la secretaría aragonesa, de manera que solo había un secretario que pudiese ocuparse del secreto y acudir a la audiencia: Urbán Fernández de Terroba. Éste llevaba tiempo realizando algunas ausencias por circunstancias personales y los inquisidores, aun con Fernández de Terroba allí, necesitaban urgentemente alguien que rellenase los huecos en el secreto. Pero es que, además, Fernández de Terroba había sido suspendido de su oficio por haberse casado sin permiso de la Suprema. Ese mismo año ya habían solicitado los inquisidores el nombramiento de algunos secretarios, dado que la hacienda del tribunal se encontraba un poco más saneada que en el pasado, pero la respuesta de la Suprema les instaba a buscar ayuda dentro del propio tribunal, es decir, intentar contar con otros oficiales. Los inquisidores debieron quedar desconcertados y, más aun, cuando, teniendo en cuenta los ánimos de algunos de los oficiales, pronto se percataron de que no podían contar con ellos. No había quien asumiese las funciones, o al menos parte de ellas, de los secretarios del secreto.

Por un lado se encontraba Juan Jaime Esporrín, que había estado durante años sirviendo como ayudante en el secreto y ahora era contador del tribunal. Los inquisidores dudaban sinceramente de que éste quisiera aceptar volver a echar una mano en el archivo y en las labores administrativas, en especial en lo que tenía que ver con el despacho en la audiencia, que era de las cosas que más apremiaban. Durante los años en que había estado ayudando en el secreto, nunca se le había permitido acudir a la audiencia y, además, en no pocas ocasiones se le habían negado ayudas de costa y otras retribuciones por su trabajo, aun cuando empezó a compaginar el oficio de contador con la ayudantía esporádica, así como con sus otros cargos fuera del tribunal. Esporrín debía estar cada vez más desencantado con la actitud del Santo Oficio hacia su persona, y tanto es así que empezó a au-

\footnotetext{
${ }^{61}$ AHN, Inquisición, Libro 974, fol. 192r.
} 
mentar sus ausencias y acabó apartándose del servicio del secreto. Los inquisidores, sabiendo cómo se había portado la institución con él, puede decirse que no se atrevían ni a plantearle la cuestión ${ }^{62}$.

La segunda opción era el receptor, pero con éste las cosas parecían estar aún más difíciles. En principio, se excusaba por la cantidad de trabajo que le daba la gestión de la hacienda, pero la verdad es que los inquisidores tenían ciertas reticencias hacia su persona y pensaban que pondría dificultades. $\mathrm{Y}$ a todo esto se añadía que, tanto Esporrín como el receptor, eran ambos naturales del reino, lo que a ojos de los inquisidores suponía un problema ${ }^{63}$. Llevaban tiempo reclamando secretarios ajenos al reino, pues en su opinión con los naturales siempre existía el riesgo de que, de una u otra forma, intentaran socavar la autoridad del Santo Oficio. Algo que sería sencillo si se hacía desde el propio sanctasanctórum de la institución: el secreto. Los inquisidores, en definitiva, se veían en la necesidad de solicitar a la Suprema el envío de un notario de mui buena pluma y capaçidad, a la vez que, de manera solapada, rompían una lanza a favor de que se alzase la suspensión de Urbán Fernández de Terroba ${ }^{64}$.

Pero no siempre estas situaciones, en las que unos secretarios ausentes o simplemente sobrepasados debían ser complementados con otros oficiales, fueron del agrado de la Suprema. El secreto era un bien demasiado preciado como para permitir la entrada a cualquiera, aunque se tratase de otros miembros de la institución. Su acceso era restringido y se necesitaba de permisos especiales para poder cruzar su umbral, debido a la importancia y el contenido de los documentos que custodiaba. Normalmente, debido a la necesidad, se toleraba estos movimientos de oficiales en los tribunales, pero eso no quiere decir que la Suprema estuviese excesivamente complacida, o al menos no lo estuvo en algunos casos. Aunque también es cierto que las contrariedades en la Corte, excepto varias salvedades, parece que se concentran en el primer siglo de actividad de la institución. Con seguridad, las nuevas problemáticas que fueron surgiendo con el tiempo y el crecimiento experimentado en la Inquisición, hicieron cambiar de opinión a la Suprema, que fue siendo cada vez más flexible ante estas coyunturas.

Un ejemplo de disconformidad fue la mostrada, nada menos que, por el Inquisidor General Fernando de Valdés en 1559. Los secretarios del secreto del Tribunal de Sevilla se encontraban desbordados por la cantidad de trabajo y, en el pasado, los inquisidores ya habían pedido permiso para que el receptor, Domingo

${ }^{62}$ AHN, Inquisición, Libro 979, fol. 357r.

63 AHN, Inquisición, Libro 979, fol. 357r.

${ }^{64}$ AHN, Inquisición, Libro 979, fols. 357r-v. 
de Azpeitia, pudiese echarles una mano. Pero entonces la negativa de Valdés había sido rotunda. En ese año, la situación parece que era insostenible, de manera que el Inquisidor General se vio obligado a relajar su postura y aceptar la asistencia en el secreto de Azpeitia, algo que iba en contra de sus propias convicciones, porque no es bien que entiendan en las cosas del secreto los que no fueren dél ${ }^{65}$.

Por otro lado, también podía suceder que aquellos oficiales a los que se cometía el trabajo de otros, no lo desempeñasen con la suficiente eficacia. Esto no se debía a sus aptitudes, sino a su "actitud”, pues pensaban que aquellas labores no eran propias de su puesto y que, al fin y al cabo, no les incumbían. En 1568, por ejemplo, el Tribunal de Toledo contaba solo con dos secretarios y, debido al importante número de causas que se encontraban abiertas, los inquisidores estaban despachando en dos audiencias a la vez, de manera que cada uno de los secretarios asistía a una de ellas. Por consiguiente, nadie se estaba ocupando del secreto, ni de otras gestiones propias del oficio. Se decidió contar entonces con el secretario de bienes confiscados, Juan de Vergara, pero éste estaba poniendo algunas dificultades. Los inquisidores escribieron a la Suprema en busca de una solución. Solicitaban el nombramiento de un nuevo secretario, pero, en lugar de prescindir de Vergara, en vista de su comportamiento, pensaban que era la persona idónea para el puesto y que su actitud cambiaría en cuanto se le expidiese el título de secretario del secreto. En cualquier caso, no podían prescindir de su ayuda. Llevaba varios años apoyando a los oficiales del secreto y conocía su funcionamiento, y a ello se añadía el hecho de que era la persona que al presente más notiçia tiene de genealogías y antigüedades de Toledo y su distrito de todos los que al presente ay en este ofiçio, que no es lo que menos inporta para muchos efetos ${ }^{66}$.

\subsection{Los secretarios de actos positivos}

Este oficio de nuevo cuño, inexistente en los orígenes del Santo Oficio, tenía como finalidad liberar a los secretarios del secreto de realizar las informacio-

${ }^{65}$ Los días passados os escrivimos que, porque el receptor Domingo de Azpeitia estuviese más libre para entender en los negocios çeviles, no le ocupásedes en lo del secreto. Y agora hemos savido que, por star el juez de bienes ocupado en la vista dessos negocios, no puede entender en lo de su audiencia. Y así el rreceptor está desocupado y, pues en ansí y ay tanta neçesidad de que essos negocios de los presos se despachen y que no bastará Arrieta, converná que encarguéis al rreceptor que entienda en ello como fasta aquí. Y las cartas que nos escriverdes de negocios, estando aý los notarios del secreto, no ay necesidad que se escrivan con otros de fuera. Y en esto hágase lo que os tenemos escripto, porque no es bien que entiendan en las cosas del secreto los que no fueren dél (AHN, Inquisición, Legajo 575, fol. 117v).

${ }^{66}$ AHN, Inquisición, Legajo 3.069, expediente 105. 
nes de limpieza de los nuevos candidatos a la institución, aunque solo en lo referente a la recepción y el traslado de testificaciones, ya que no podían intervenir en otro tipo de documentos. Su establecimiento se produjo a mediados de siglo XVII y solo se accedía a él mediante la compra, es decir, abonando una cierta cantidad de dinero al tribunal al que pertenecía la plaza, aunque ésta acabase revirtiendo en la Suprema. Detrás de su implantación, además de la razón práctica anteriormente expuesta, había una importante causa económica. El rey Felipe IV necesitaba con urgencia capitales para mantener su imperio militar y había exigido a la Suprema que se implicase más en su política. De esta forma, disimulados hábilmente como un provecho para la defensa de la Santa Fe Católica, el Inquisidor General, Antonio de Sotomayor, ordenó la venta de varios oficios en 1641-1642. Entre ellos se encontraba la notaría del juzgado de bienes confiscados y, también, la secretaría de actos positivos. Con el beneficio obtenido, la Suprema aportaría a las contiendas del monarca un contingente de 150 soldados de caballería ${ }^{67}$. Esta realidad, lejos de esconderse, se reflejaba incluso en los propios títulos de nombramiento, en los que quedaba constancia de la decisión real y como había sido con su connivencia como se había dispuesto la venta de los oficios.

Curiosamente, a pesar de llevar la denominación de "secretarios del secreto de actos positivos”, su figura no podía estar más alejada de la de los verdaderos secretarios del secreto, aunque fuesen de carácter supernumerario u honorífico. De hecho, para empezar, ni tan siquiera estaban autorizados para entrar en el secreto, lo que, de por sí, ya da una idea de lo limitado de sus funciones. De igual modo, al no poder dedicarse más que a las testificaciones relativas a las informaciones de limpieza, no podían participar de los mismos derechos que el resto de secretarios, de manera que sus ingresos se reducían a aquellos que percibían por realizar las informaciones, tanto dentro del tribunal, como fuera de él. El oficio de secretario de actos positivos era, por tanto, muy restrictivo y estaba sujeto a toda una serie de condiciones que, afortunadamente, quedaron especificadas en los primeros títulos que se expidieron. Uno de ellos, otorgado en febrero de 1642 por Antonio de Sotomayor a favor de Melchor Velázquez de Roa, regidor en Valladolid, para el Santo Oficio de aquella ciudad, es un buen ejemplo de estas concesiones en sus momentos iniciales. Éste se había hecho con el puesto tras comprometerse a pagar nada menos que 2.500 ducados de vellón, siendo él el que más se había adelantado entre otras personas, lo que indica que había otros interesados en la plaza. Lo que no se especifica es si el nombramiento se efectuaba por, como dice, haberse

\footnotetext{
${ }^{67}$ AHN, Inquisición, Libro 375, fol. 165r.
} 
“adelantado” Velázquez de Roa y haber sido el primero en presentar su candidatura, o por otras cuestiones, como haber ofrecido más dinero que sus competidores o ser mayor su solvencia. Otros factores, como su vinculación a la institución o ciertos méritos también pudieron tenerse en cuenta, pero no se deja constancia de ellos $^{68}$. Tampoco se presupone que en la elección hayan intervenido, precisamente, las cualidades del sujeto para desempeñar el oficio, algo que, sin duda, tendrá mucho que ver con la habilidad y eficacia con las que lo ponga en ejecución. O, mejor dicho, con lo que podría considerarse la ausencia de ellas. Afortunadamente, una de las prerrogativas que tenían los secretarios de actos positivos era la de nombrar un sustituto en su lugar, un "teniente” de su plaza.

Como ya se ha mencionado, el caso de Velázquez de Roa es un buen ejemplo de los primeros títulos concedidos y merece la pena detenerse en cuáles eran las condiciones que caracterizaban su nombramiento, así como los de otros oficiales de esta misma categoría ${ }^{69}$.

- En primer lugar, tenían las mismas prerrogativas que el resto de secretarios del secreto, pero no podían actuar en causas u otros asuntos de fe, más que en las informaziones por actos positivos.

- Carecían de salario y no percibían ayudas de costa. Sus únicos ingresos procederían de las informaciones que realizasen. Los derechos a cobrar estaban estipulados en doce ducados de vellón por cada información, estando obligados a interrogar, al menos, a seis testigos en cada una de ellas. En el supuesto de que, para hacer las investigaciones, tuviesen que desplazarse fuera de la ciudad donde el tribunal tenía su sede, a cualquier lugar del distrito, recibirían la misma cantidad que los secretarios del secreto ${ }^{70}$.

- Al examinar a los testigos, debía ir siempre acompañado por el comisario que determinase el tribunal. Los interrogatorios nunca podrían hacerse en la

\footnotetext{
${ }^{68}$ La expresión formulística que aparece en el título referente a su servicio al Inquisidor General y a la Suprema (havéis servido a nos y al dicho Conssejo...) no corresponde a méritos pasados, sino al pago que efectuará Melchor Velázquez de Roa de los 2.500 ducados de vellón por su oficio, lo que suponía un hecho de considerable estimación a ojos de Antonio de Sotomayor (AHN, Inquisición, Libro 375, fol. 165r).

${ }^{69}$ AHN, Inquisición, Libro 375, fols. 165r-167r.

${ }^{70}$ En el caso de Velázquez de Roa, en el Tribunal de Valladolid, éste percibiría el salario hordinario de mill maravedís que se da a los notarios del secreto por los días que gastáredes en yda y buelta. Sin embargo, por los interrogatorios de los testigos propiamente dichos, solo podría cobrar la cantidad estipulada de doce ducados, los mismos que si les examinase en la misma ciudad de Valladolid (AHN, Inquisición, Libro 375, fol. 166r).
} 


\section{BÁRBARA SANTIAGO MEDINA \\ EN LO PROFUNDO DE LA FRÁGIL MEMORIA: LOS “OTROS” SECRETARIOS DEL SANTO OFICIO}

sala del tribunal, ni en presencia de los inquisidores, sino solo del comisario y en el lugar que eligieren los propios secretarios de actos positivos.

- Solo podrían entrar en el tribunal y despachar con los inquisidores si eran requeridos por estos.

- Si, por enfermedad o cualquier otra circunstancia, no podían acudir a hacer las informaciones, podían designar a un sustituto, siempre que éste contase con la aprobación de la Suprema o del tribunal para el que trabajaban. En caso de que las informaciones de limpieza fuesen para un candidato a oficial del Santo Oficio, solo podría hacerlas un secretario del secreto. Tanto en uno como en otro supuesto, el secretario de actos positivos era quien debía correr con los gastos derivados de las informaciones, costeando de su propio bolsillo a su sustituto.

- Tenían la prerrogativa de exigir un compromiso por parte de los pretendientes que adujesen tener los consabidos actos positivos en sus genealogías, por el cual se obligaban a pagar lo que costase hacer sus informaciones. De esta forma se aseguraban percibir los derechos por su trabajo, ya que muchos pretendientes, debido al monto final de las pruebas, trataban por todos los medios de resistirse a abonarlo.

- En cuanto a antigüedad y participación en actos públicos del Santo Oficio, tendrían los mismos privilegios que el resto de secretarios del secreto.

- Sus hijos y nietos podrían beneficiarse de la exención de obligatoriedad para hacer informaciones de limpieza en caso de que deseen entrar a formar parte del Santo Oficio. Solo las mujeres que casasen con estos deberían someterse a la investigación inquisitorial.

- Si falleciesen estando en posesión de su oficio, sin haber nombrado a alguien que les sucediese en el mismo, pasaría a su hijo mayor o a quien tuviese derecho a su herencia.

- El oficio sería perpetuo y permanecería en sus “casas”, a menos que ellos decidieran elegir como sucesores a alguien ajeno a ellas. En cualquier caso, los seleccionados debían reunir las partes y calidades nezesarias.

Normalmente, al tratarse de una cantidad tan elevada la que había que desembolsar por el oficio, se permitía a los beneficiarios realizar los pagos de manera fraccionada, aunque se les daba un plazo para efectuarlos. En el caso concreto de 


\section{Bárbara SANTIAGo MEdiNa \\ EN LO PROFUNDO DE LA FRÁGIL MEMORIA: LOS “OTROS” SECRETARIOS DEL SANTO OFICIO}

Velázquez de Roa en Valladolid, el Inquisidor General ordenó que debía pagar los 2.500 ducados de vellón en diez meses. El primer pago se haría efectivo a los dos meses a contar desde la fecha de la toma de posesión del oficio y, el último, el día de San Juan de ese mismo año de $1642^{71}$.

También en febrero de 1642 fue nombrado, esta vez para Cuenca, Juan de Montemayor y Córdoba, regidor perpetuo de aquella ciudad, quien abonó por el oficio la cantidad de 1.550 ducados de vellón ${ }^{72}$. Una cantidad sensiblemente menor que la que había pagado, casi en las mismas fechas, Melchor Velázquez de Roa por el suyo en Valladolid. En abril de 1642 fue Jacinto Eliz Cidrón quien se hizo con la secretaría de actos positivos de Santiago, a cambio de 18.000 reales, la terçia parte dellos en platta ${ }^{73}$.

En 1654 la Suprema, tras una consulta elevada al rey Felipe IV, ordenó a los tribunales de distrito dejar de hacer las informaciones por actos positivos, de manera que, a partir de ese momento, se harían en la forma ordinaria y en los lugares de sus naturaleças ${ }^{74}$.

\section{CONCLUSIÓN}

Supernumerarios, ayudantes, sustitutos..., todos estos apelativos no son más que reflejo de una compleja realidad que, con demasiada ligereza, los historiadores del Santo Oficio han dejado caer en el olvido. El presente artículo, en definitiva, ha tratado de ahondar en estas figuras que complementaban la de los secretarios del secreto y sin las cuales los tribunales de distrito no hubiesen podido abordar la cantidad y diversidad de tareas que les estaban encomendadas desde el poder real y la Suprema. Muchos de los individuos que desempeñaron su trabajo bajo estas denominaciones no llegaron nunca a convertirse en oficiales titulados ni, por supuesto, a alcanzar los privilegios de los que estos gozaban. Algunos incluso fueron traicionados por esa institución a la que servían y de la que esperaban cierta compensación. Unos se alejarían de ella como amantes despechados; otros, menos afortunados, fallecerían sin saber si al menos sus descendientes alcanzarían la dignidad que ellos tanto ansiaron.

\footnotetext{
${ }^{71}$ Estas fechas no coinciden con los diez meses estipulados, si bien son las que constan en el documento (AHN, Inquisición, Libro 375, fol. 166v).

${ }^{72}$ AHN, Inquisición, Libro 375, fols. 170v-172v.

${ }^{73}$ AHN, Inquisición, Libro 375, fols. 186r-187v.

${ }^{74}$ AHN, Inquisición, Libro 980, fols. 195r-v.
} 